\title{
THE FAIR LABOR STANDARDS ACT IN THE WAR ECONOMY
}

\author{
PhILIP B. FIBMING*
}

The increasing rate of technological change over the last century has profoundly affected every aspect of life, including the art of war. Indeed, war constantly becomes less of an art and more of a science.

The modern soldier is not a Sir Galahad riding forth in shining armor to singlehanded combat. He is a technician. If properly trained for his task he will have expert knowledge of one or more complicated mechanical devices-the internal combustion engine, the radio transmitter, the camera, the airplane detector. As a matter of course he will be familiar with one or more pieces of ordnance, know how such instruments function and how they are constructed. He will have some knowledge, ranging up to expertness, in one or more technical fields-chemistry, aerodynamics, hydraulics, meteorology, road and bridge engineering, camouflage. At no previous time in history has so much in knowledge and skill been demanded of the patriot. As a consequence, the work of war touches our whole civilization, especially at the points where it is most complex. All sorts of intricate devices must be manufactured in great quantities, for almost everything modern technology can produce is useful in all-out conflict.

The American Civil War has been called the first of the modern wars. It was modern in the sense that it foreshadowed the development of many technical devices (the ironclads Monitor and Merrimac are examples) that since have come into general use, and also because it came to involve something approaching a total effort on the part of rival economies. For each man at the front in $186 \mathrm{r}$, the labors of two or three men behind the lines were necessary. Accelerating technological change had greatly increased the ratio by r9r7. The process has continued. If we assume an eventual American Army of seven or eight million men, it is obvious that the entire civilian adult population must be geared into the war effort in some degree, especially since we must also assist in equipping the men of the United Nations allied with us in the present undertaking.

\footnotetext{
- rg07-1909, University of Wisconsin; B.S., I91x, United States Military Academy; 1912-I913, Army Engincering School. Brigadier General, United States Army. Administrator, Federal Works Agency, since 1941. Exccutive officer and Deputy Administrator, Public Works Administration, 1933-1935; in charge, Passamaquoddy Project, 1935-1936; Coordinator, Resettlement Administration, 1936-1937; District Engineer, St. Paul, Minnesota, I937-1939; Wage and Hour Administration, 1939-1941, Administrator, 1940rg4x.
} 
I.

Because all of us, whether fighting at the front or working at home, are involved, to speak of the position of labor in our war economy may mislead by implying a distinction where sharp distinctions do not exist. With the entire population engaged, the civilian problem is to achieve and maintain those processes and attitudes that best promote maximum production of needed goods and services. This is true because a democracy which is fighting to maintain a free economy must rely to a very large extent upon the willing cooperation of its citizens. Methods of coercion and compulsion, which proved so successful in Germany in the first two years of the war, obviously are not available to us. We cannot use them without giving hostages to the enemy, without emptying our declared purpose of its essential meaning.

Labor unions were suppressed in Germany before the war. Since I939 drastic controls of various types have been intensified and extended over the activities of the ordinary citizen. $\mathrm{He}$ is told where, when, and how long he must work and the wage he will receive. He has little or no choice in the matter. In the early stages of an offensive war, close regimentation of this sort possesses decided advantages over the slower and less "efficient" processes of democratic free enterprise. The German worker's distaste of compulsion is partially compensated by the lift imparted to his morale by a rapid succession of relatively inexpensive victories in the field. It remains to be seen how he will react in a time of reverses when victories are no longer easy, quick, or inexpensive.

That the free worker bears up well under military adversity is proved in Great Britain where morale has survived many reverses, and has even grown in intensity under the pounding of long-sustained air raids.

While some measure of control is essential in war time even in a democracy, it must be fashioned primarily to encourage each to make his maximum voluntary contribution. When controls become too intolerable to be borne, the free worker, by his participation in the governmental process, can relax or modify them, a method of redress which is closed to the citizen of the totalitarian state.

Unhappily, there are in the United States those who secretly admire the superficial, though short-term, "efficiency" of Fascism and who would like to apply its techniques to our war effort. And there are some who see that the struggle over the division of the national income as among ownership, management, and labor is far older than the conflict of arms in Europe and Asia and who expect it to continue long after the war has been fought to its conclusion. They are reluctant to see introduced new factors that threaten to disturb present arrangements respecting the division of income, and on both sides of the domestic conflict a few would take advantage of the national emergency to strengthen their own position.

Actually, if we accept the overwhelming importance of winning the war, there should be no spoils to divide. Neither labor nor industry can expect anything but slavery if we lose, and, therefore, any contribution which must be made toward winning the war is a proper democratic contribution. It should be said in all fairness, 
however, that the great majority of employers are not now finding fault with labor. They have learned by experience that the demands of workers are not always unreasonable or necessarily unpatriotic. They know that differences, given a spirit of mutual understanding and good will, yield to negotiation.

A tragic disservice has been rendered the Nation by those who have sought to use the divide-and-conquer technique against labor. Our problems are so great and pressing that there can be no hope of solving them satisfactorily until we apply to them our best intelligence. Emotion will not do it.

The unthinking or the irresponsible have released much propaganda intended to foment discord among the workers themselves, to divide the public in its attitude toward labor, and even to turn the soldier at the front against the worker at home by emphasizing the disparity of condition between the private fighting for \$2I a month and the worker earning a dollar an hour and time and a half for overtime. The fact that, in addition to his $\$ 21$ a month which has since risen to $\$ 50$, the private receives shelter, food, clothing and medical attention is not irrelevant but is seldom mentioned. Moreover, an unavoidable disparity between the soldier and his brother at home has existed in every war. What needs to be stressed is that today's citizensoldier ordinarily is but a worker in uniform, that his father and brothers at home also are workers, and that, since he eventually must return to his former status as an employee of industry, he has a very great personal stake in the maintenance of proper labor standards.

Strikes are expensive at any time, but little effort is made during war to analyze and eliminate their causes. An example of unquestioning acceptance of propaganda against labor may be found in the widespread publicity that accompanied an alleged strike of shipyard workers on the West Coast early in the year.

The workers had a collective bargaining agreement calling for an eight-hour day and time and a half for overtime. The employer desired to introduce two ten-hour shifts. The workers alleged the existence of a considerable supply of unemployed shipyard workers in the community and contended that the employer should put three eight-hour shifts to work, an arrangement which would have resulted in 24 hours of production daily instead of the 20 which the employer demanded. If the position of the workers was valid, more man-hours would have been worked under the arrangement they suggested, but virtually no effort was made to ascertain for the public the truth or falsity of their argument. Their refusal to work the ten-hour shift was widely represented as a strike little short of treason and another example of unconscionable grasping for additional benefits. Actually, under the three eight-hour shifts proposed, workers' pay would have been decreased by the cancellation of overtime.

2.

Organized labor entered the First World War with about half of its present numerical strength. The 48-hour week was coming into general acceptance, and the official policy of the Government, as expressed by General William Crozier, Chief of 
Ordnance, in his famous General Order $\mathrm{r}_{3}$, was for the retention of all safeguards that had been built up for the protection of the workers.

Wage rates went up and earnings rose even more sharply because of overtime pay. On the whole, it was a lush period, even though living costs also were rising. Workers wandered about from plant to plant in search of more and still more overtime work. The confusion was so great and the chaotic turnover so detrimental to productive efficiency, that the War Labor Policies Board finally was driven to consider the necessity for universal wage stabilization, but peace intervened before action in that respect was taken. The silk shirts frayed out in the post-war wash, when overtime work was discontinued and earnings were sharply curtailed. Living costs were still rising, and labor then discovered that its gains had been largely ephemeral. On the whole, the workers emerged from the war in a worse position than when they entered it.

With history showing signs of repeating, it is highly desirable that wage stabilization in the present war should be no longer deferred. It is all the more essential because labor has voluntarily relinquished the right to strike, and the War Labor Board of necessity must have some wage standards for its guidance in settling disputes.

Wage stabilization is not to be confused with wage freezing, which some have advocated. To freeze the wage structure at existing levels, or at a level existing at some prior date, would mean the freezing of inequalities and injustices also. It would freeze wages which are admittedly much too low, as well as those which may be considered to be too high, or high enough. It would accentuate a natural dissatisfaction among workers occasioned by the fact that men doing identical work in different plants, and sometimes in the same plant, are being paid at different rates. The need is for a type of stablization that will first bring up the lower-paid workers to a living wage, put an end to wage discriminations among men doing similar or identical work, and provide for future adjustments when necessary to compensate for increases in the cost of living.

As long ago as January, I94I, I suggested that the industry-committee mechanism of the Wage and Hour Law might very well be utilized to bring about stabilization without the necessity for the creation of additional administrative machinery.

That statute, ${ }^{1}$ it will be remembered, sets a present minimum wage of 30 cents an hour for employees engaged in interstate commerce, or in the production of goods for interstate commerce, with a 40-cent minimum to become generally effective October 24, I945. To permit such industries as can do so, without substantially curtailing employment, to adjust to a minimum higher than 30 cents (but not higher than 40) before I945, the Administrator is required to issue industrial wage orders from time to time upon the recommendations of industry committees. ${ }^{2}$ Each industry committee, appointed by the Administrator, must include in equal numbers representa-

${ }^{2} 52$ STAT. 2060 (1938), 29 U. S. C. \$\$201-210.

The Summer, I939, issue of Law and Contemporary Problems (Vol. VI, No. 3) was devoted to a symposium on "The Wage and Hour Law." Ev.

${ }^{2}$ Provision is made for wage orders in $\$ 8$ of the Act. 29 U. S. C. $\$ 208$. 
tives of the public and of the employers and employees in the industry concerned. The committee is required to study economic and competitive conditions in the industry for which it serves, and the Administrator is required to make available to it such data as may be in his possession bearing upon the problem, the committee may call upon him to submit additional data, and it may subpena witnesses and documents and undertake independent studies of its own. Generally, the 40 or more industry committees that so far have made wage recommendations have had access to the studies of the Wage and Hour Division's own economists, of the Bureau of Labor Statistics and other governmental agencies, and have had before them materials submitted by trade associations, labor unions, and by individual employers and employees.

The deliberations of the committees are not wage negotiations or arbitration proceedings, in the ordinary sense. They are fact-finding proceedings and the conclusions and recommendations must be of such a nature as to meet the test of public hearings before the Administrator and possible later challenge in the courts.

With two or three exceptions, all the wage orders issued in accordance with this process have been accepted as generally satisfactory by both the employers and employees directly concerned, and every wage order that has been challenged in litigation has been upheld by the courts.

The problem of recommending defensible maxima differs from that of establishing minima in degree but not in kind, and the industry-committee technique would seem to be admirably suited to the purpose.

From a system of equitable wage stabilization, if combined with adequate price controls or rationing, we should expect a number of benefits: interruptions of production in war plants due to labor turnover would be greatly reduced; "pirating" of workers from plant to plant would be discouraged; dissatisfaction and discontent among workers because of inequalities would be greatly moderated; and finally both labor and industry would be in a far better position to face inevitable post-war readjustments.

3.

The recent attack upon the Wage and Hour Law, in my opinion, was detrimental to that national unity which we all concede to be essential in war time. The nature of the law was so badly distorted by its enemies that many patriotic persons were utterly confused. It seems necessary to point out again that the law sets no limit to the number of hours that may be worked in one day or in one week. Its only requirement as to working time is that, if the covered employee works more than 40 hours in one week, he shall be paid for the excess at time and a half the regular rate at which he is employed. The purpose of this provision was not, as some have supposed, to increase the earnings of the individual employee, but to spread the work, since straight time is cheaper than overtime.

To point out, on the one hand, that the provision has had the effect of increasing employment, and, on the other, that it has not prevented long hours of work in 
essential war industries, involves no necessary inconsistency. What obviously is happening is that in those plants in which additional workers can be trained and absorbed, they are being employed; in situations in which overtime work cannot be avoided, longer hours are being worked.

The Bureau of Labor Statistics reports that in January of this year, $89.2 \%$ of the plants in the aircraft industry (including engines and propellers) were working roo hours or more; as were $98.5 \%$ of blast furnaces; $92.8 \%$ in brass, bronze and copper products; all chemical plants, all engine plants (other than aero); $71.4 \%$ of machine tool plants, $79.4 \%$ of machine tool accessory plants, $85.1 \%$ of the ordnance plants, $86.2 \%$ of shipbuilding yards, $97.8 \%$ of smelting and refining plants, and $69.1 \%$ railroad cars and locomotive plants. A majority of all plants in primary war production were working more than roo hours a week, and a very large number had reached or exceeded $\mathrm{I} 60$ hours a week. In the latter category were $37.5 \%$ of the airplane plants, $30 \%$ of the aluminum plants, $80.3 \%$ of the blast furnaces, $53.6 \%$ in brass, bronze and copper products, $85 \%$ of the chemical plants, and a third of the shipbuilding yards.

Such schedules, of course, were made possible only by the use of multiple shifts.

Average hours worked by individual workmen had achieved new high levels in the first half of December, I94I, according to the Bureau. The period covered by the survey includes the week before the attack on Pearl Harbor, and a week or more thereafter, but the report does not reflect the entire impetus to the productive effort following our entrance into the war. The average hours worked per week in some leading war industries during the period covered, follow:

\begin{tabular}{|c|c|}
\hline Industry & $\begin{array}{l}\text { Average houts } \\
\text { yorked per week }\end{array}$ \\
\hline Fire arms ... & 52.5 \\
\hline Machine tools $\ldots \ldots \ldots \ldots \ldots \ldots \ldots \ldots \ldots \ldots \ldots \ldots \ldots \ldots \ldots$ & 53.8 \\
\hline 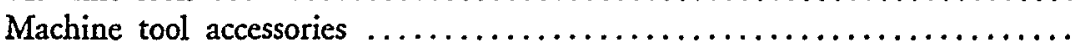 & $54 \cdot \mathrm{r}$ \\
\hline 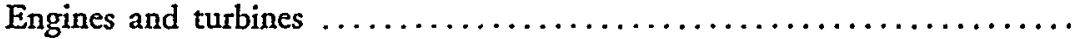 & 49.9 \\
\hline 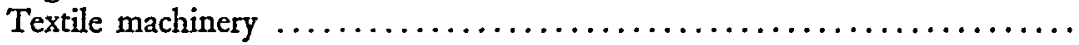 & 48.5 \\
\hline Forgings, iron and steel $\ldots \ldots \ldots \ldots \ldots \ldots \ldots \ldots \ldots \ldots \ldots \ldots \ldots \ldots \ldots \ldots \ldots \ldots \ldots \ldots \ldots$ & 47.1 \\
\hline 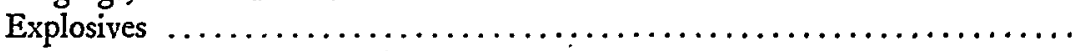 & 47.0 \\
\hline Cars, electric and steam railways $\ldots \ldots \ldots$ & 42.4 \\
\hline 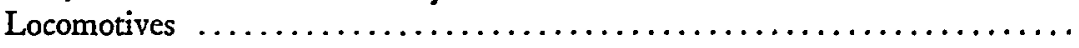 & 46.7 \\
\hline Foundries and machine shops $\ldots \ldots \ldots \ldots \ldots \ldots \ldots \ldots \ldots \ldots \ldots \ldots \ldots \ldots \ldots \ldots \ldots \ldots$ & 46.3 \\
\hline 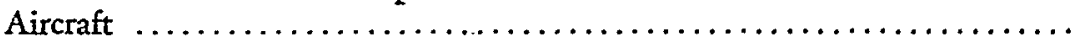 & 46.2 \\
\hline 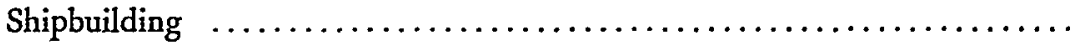 & 46.0 \\
\hline 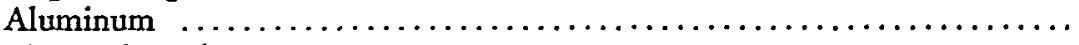 & $45 \cdot 7$ \\
\hline 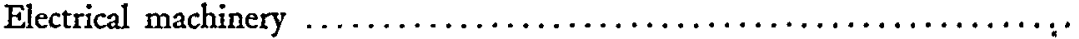 & 44.7 \\
\hline Brass, bronze and copper products $\ldots \ldots \ldots \ldots \ldots \ldots \ldots \ldots \ldots \ldots \ldots \ldots \ldots \ldots \ldots \ldots \ldots$ & 44.5 \\
\hline Ammunition & $44 \cdot \mathrm{x}$ \\
\hline
\end{tabular}

Source: Report of Bureau of Labor Statisties for the first half of December, x94r.

These figures represent an understatement of the hours worked by many individuals in the industries to which they refer, since they include data for those who did not need to work overtime, as well as for those who worked 60,70 , or even more hours a week.

A more accurate picture of the hours situation is afforded by the following table, 
which shows the percent of employees working overtime in January, and the average number of hours worked by those working overtime:

\begin{tabular}{|c|c|c|}
\hline Industry & $\begin{array}{l}\text { Percent } \\
\text { working } \\
\text { overtime }\end{array}$ & $\begin{array}{l}\text { Average hours of } \\
\text { overtime worked } \\
\text { weekly by those } \\
\text { working overtime }\end{array}$ \\
\hline Aluminum manufactures : & 57.2 & 9.9 \\
\hline 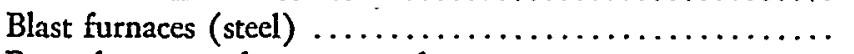 & $28 . \mathrm{I}$ & $9 \cdot 3$ \\
\hline Brass, bronze and copper products $\ldots \ldots \ldots \ldots \ldots \ldots$ & 68.0 & 10.4 \\
\hline Cars, electric and steam railways $\ldots \ldots \ldots \ldots \ldots \ldots$ & 43.I & $\mathrm{rI} .4$ \\
\hline 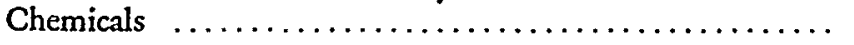 & I8.4 & 8.7 \\
\hline Copper mining $\ldots \ldots \ldots \ldots \ldots \ldots \ldots \ldots \ldots \ldots \ldots \ldots$ & 76.2 & 10.6 \\
\hline Electrical machinery $\ldots \ldots \ldots \ldots \ldots \ldots \ldots \ldots \ldots \ldots \ldots \ldots \ldots$ & 62.4 & ro.o \\
\hline Engines (except aero) & 66.5 & 14.3 \\
\hline Locomotives $\ldots . . \ldots$. & 91.2 & 12.8 \\
\hline Machine tool accessories & 95.9 & $x 5.9$ \\
\hline Ordnance (primary) $\ldots \ldots \ldots \ldots \ldots \ldots \ldots \ldots \ldots \ldots \ldots \ldots \ldots \ldots \ldots$ & 75.2 & II.3 \\
\hline Ordnance (miscellaneous) $\ldots \ldots \ldots \ldots \ldots \ldots \ldots \ldots \ldots$ & 60.4 & 10.5 \\
\hline Shipbuilding $\ldots \ldots \ldots \ldots \ldots \ldots \ldots \ldots \ldots \ldots \ldots \ldots \ldots \ldots \ldots \ldots \ldots \ldots$ & $9 \mathrm{~g} .2$ & $x 2.3$ \\
\hline Smelting and refining $\ldots \ldots \ldots \ldots \ldots \ldots \ldots \ldots \ldots \ldots$ & 25.6 & $7 \cdot 3$ \\
\hline 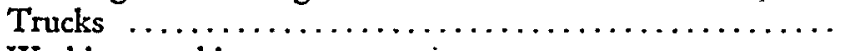 & $45 \cdot 7$ & 9.I \\
\hline $\begin{array}{l}\text { Washing machines } \ldots \ldots \ldots \ldots \ldots \ldots \ldots \ldots \ldots \ldots \ldots \ldots \ldots \ldots \ldots \ldots \ldots \\
\text { Source: Data compiled by Bureau of Labor Statistics, January, x } 94{ }^{2}\end{array}$ & 77.8 & 9.5 \\
\hline
\end{tabular}

All of the overtime indicated in the table was paid for by at least time and a half, as required by law, and in some instances, where required by collective bargaining contracts, at even higher rates. ${ }^{3}$

It has been argued that while employers may have paid the overtime rates cheerfully enough, it is the taxpayer who suffers in the long run, since the higher labor costs are passed on to him. This is true only where contracts have been let on a cost-plus basis or contain "escalator" clauses. It is not true where contracts are let on a fixed-price, or lump-sum, basis and contain no provision for adjustment to cost changes occurring after signing of the contracts. The majority of contracts, both in number and in dollar value, are in the latter category, and in such instances the abolition of overtime payments would not have resulted in lower costs to the taxpayer. But even if it could be shown that the taxpayer would benefit in every instance from the abolition of time-and-a-half pay for overtime work, the more fundamental question of broad, social policy would still remain unanswered.

The ability of employers to pay time and a half for overtime is not irrelevant, but it figured little in the Congressional debates. On the actual situation here another study made by the Bureau of Labor Statistics throws revealing light. The study embraced costs, prices and profits of 260 corporations in 26 defense industries whose combined r939 sales amounted to $\$$ II,234,000,000. It was found that an increase in working hours by $20 \%$ above those actually worked in 1939 , with full overtime wages, and conservatively assuming only a $16 \%$ increase in production, would have increased the combined earnings of the 260 corporations by $\$ 75,284,000$ all other

\footnotetext{
${ }^{3}$ It was not until March that labor voluntarily relinquished double time for Saturday, Sunday and holiday work where contracts had called for such compensation.
} 
factors remaining constant. "These conclusions," the Bureau reported, "are based on the fact that the payment of overtime rates under the Fair Labor Standards Act is more than counterbalanced by the increased utilization of plant facilities and the absorption of fixed overhead expenses in a larger volume of production."

In nine of the 26 industries the effects of overtime rates as calculated indicated a decline in return to business investment, but "the methods used in the calculations were exceptionally conservative and the changes in the return or in the gross manufacturing profit were not large enough to exceed the range of probable error of the data employed."

The gross margins on sales of aircraft reported for 1939, for example, were $\$ 51,544,000$. Eight additional hours, despite the payment of time and a half for the overtime, would have increased the gross margins by $\$ 1,208,000$. In machine tools the increase would have been $\$ 336,000$; in men's, youths' and boys' clothing, $\$ 662,000$; in machinery, not otherwise classified, $\$ 668,000$; in petroleum producing and refining, $\$ 50,044,000$.

An incidental, but important, additional effect of placing a floor under wages is that it provides an incentive to the employer to improve his operating efficiency. When other than labor costs rose an adjustment frequently made by management was to resort to compensatory wage reductions. The effect of establishing irreducible wage minima, either by law or collective bargaining, is to foreclose this method of readjusting the balance and to intensify the search for other economies.

If legislative relaxation of the overtime provision were fully effective, the result would be to reduce the wages of every man in the war industries working more than 40 hours a week. But since the vast majority of the employees in war goods plants are working under collective bargaining contracts that call for time and a half for overtime, these organized workers would not be affected, unless it is assumed that new contracts would be negotiated. In that case it is most probable that the new contracts would call for higher hourly wage rates, in order that the total weekly wage might remain approximately the same as at present. Otherwise, employers would experience considerable difficulty in attracting workers from consumer-goods industries to war industries. There is much evidence to indicate that the vast majority of the employers concerned have no desire to reopen union contracts for further negotiation at this time. They would prefer to pay the overtime at the legal rate, since they realize that after the war it will be far easier to abolish overtime work than to reduce hourly rates.

Extra payments for overtime work are of additional advantage to the employer because they enable him to attract labor from more distant points. The worker who, for example, removes from Kansas to work in a Pennsylvania munitions plant, is under considerable expense for transportation. He would be much less inclined to move, and thus conversion to an all-out war effort would be retarded, were it not for the fact that increased earnings due to overtime compensate him for the additional expense. Many employers have found such workers much more willing to work long

- Overtime Pay in Relation to Costs and Profits (1941) 53 Montr. LNs. REv. 8. 
hours of overtime than those in nearby areas. The latter, already well integrated in the community, usually prefer leisure above 40 or 48 hours a week to the additional wages that come from a workweek of 60 or 70 hours. The stranger, especially if temporarily separated from his family, has fewer opportunities to spend his leisure profitably or interestingly. ${ }^{5}$

The extent of the wage cut that men working very long hours would experience if overtime pay were abolished may be illustrated by the case of a man who in March wrote to the editor of the St. Louis Post-Dispatch as follows:

In regard to the controversy on the repeal of the 40-hour-week law that industry and some Congressmen are asking for, I am one who, since the emergency began, have been working $7 x$ hours a week-eleven hours a day and eight hours on Saturday and Sunday, night work to boot.

I am termed a machinist. I am required to furnish my own precision tools, which are very costly. For this 7 h hours a week I receive $\$ 68$ a week.

My four children scarcely recognize me, as I only see them for an hour on Sunday.

For the purposes of his letter this man may have rounded both the hours worked and the wage earned. But accepting the letter at face value and assuming that its author is being paid in accordance with the law, his base rate is 78.6 cents an hour. For each hour over $4^{0}$ he is being paid once and a half that rate, or $\$$ r.I8 an hour. Eliminate his overtime pay and his weekly wage is immediately cut from $\$ 68$ to \$55.82. To me, at least, this does not seem to be the course best calculated to make better patriots of our working people, put an end to labor unrest, prevent strikes, and get the goods to the firing line more quickly and abundantly.

Although the National Association of Manufacturers opposed the enactment of the Wage and Hour Law and has done some criticizing since, it is interesting to note that not even from that source did the advocates of suspension obtain support. According to newspaper accounts, Mr. William P. Witherow, N. A. M. president, "apparently surprised some members of the House Naval Affairs Committee when he testified that there was a lot of difference of opinion within his organization as to whether suspension of time-and-one-half payments after 40 hours in a week would accelerate or retard the output of war materials. Mr. Witherow, head of the BlawKnox Company, a Pittsburgh steel concern with many war contracts, said that whether the 40-hour standard week should remain or go was, after all, an issue between the government and the taxpayer."

During the two years I was Administrator of the Wage and Hour Division of the Department of Labor I received not more than four or five letters from manufacturers complaining that the time-and-a-half requirement for overtime was working to curtail production of war goods. I had urged employers to strive for greater output not by lengthening the working week but by employing additional help and, wherever possible, by adding additional shifts so that plant and equipment could be operated 24 hours a day and seven days a week. This was in line with what

${ }^{8}$ In April plants in the New York area making war goods were advertising for skilled workers in the classified columns of the New York Times. Most of the advertisements stressed "plenty of overtime" as among the attractions. 
Mr. (now Lieutenant General) William Knudsen also had advocated. While those few complaining employers had protested that, for one reason or another, they could not put on additional employees, or increase the number of shifts, subsequent investigation showed that nearly all of them finally had made such adjustments and found them to be satisfactory.

4 .

The analogy some have attempted to draw between the Fair Labor Standards Act and the French 40-hour law has been so often discredited that I shall touch upon it very briefly and only because the argument occasionally continues to be used.

- The French 40-hour law was instituted by the Blum Popular Front Government in June, I936. It was so drawn and administered that in actual operation it tended to discourage any overtime work whatever. While provision was made whereby labor employed in defense industries could be worked longer than 40 hours, administrative difficulties were such that labor inspectors were inclined to discourage such exceptions. In effect the application of the law tended to limit hours of production as well as the hours of the individual worker. When management had used up its 40 hours, the doors of the factory were locked and everybody went home for the remainder of the week. The use of additional shifts, so that production would proceed around the clock, was difficult. Since the law required that the worker should be paid the same weekly wage for 40 hours as he previously had received for 48 hours, labor costs were increased to the employer by about $20 \%$.

Even so, Pierre Cot, former Air Minister in the French cabinet, is authority for the statement that, during the two years the 40-hour law was in effect, factory output increased over the level it had reached immediately before the law was enacted and was considerably higher than that attained immediately after it had been discarded.

But, in any event, the Wage and Hour Law differs from the French law in that it imposes no limit upon either the worker's hours or factory hours. It does not add to labor costs unless overtime is worked. It does not discourage additional employment or the utilization of additional shifts; on the contrary, it encourages re-employment and the use of multiple shifts.

It also has been assumed and argued that British industry is producing under no such limitations as those involved in the Fair Labor Standards Act. While it is true that British workers generally are working longer hours than American workers, it is also true that British labor is being paid extra for hours worked beyond what was the normal workweek in peace time. This, extra pay for extra work, is no less than is required by our Wage and Hour Law.

Working hours were greatly lengthened after the debacle at Dunkirk. In August, 1940, however, they were reduced by order of the Ministry of Labour which had found output beginning to decline. A wealth of literature from the last war testifies to the deleterious economic and social effects of too long hours of work. Only for the more robust workers was the 60- or 70 -hour week actually achieved. Others lost many hours because of sickness induced by fatigue. Accidents increased and long 
hours signally failed to maximize production. Britain's experience in the present war affords an abundance of the same sort of evidence. Some lessons are learned very slowly and painfully.

In Germany, where hours were lengthened and overtime pay was abolished early in the present war, results were equally unsatisfactory. The Government charged sabotage and dealt most harshly with the suspected saboteurs without improving production. It was not until the repressive measures had been somewhat relaxed, hours had been shortened, and pay for overtime was restored that the situation improved.

The experience of every industrial country shows the maintenance of some labor standards to be imperative in time of war.

Given adequate training programs, and with so large a potential labor supply as we undoubtedly possess, it is altogether unlikely that we shall arrive at a point within the predictable future where general relaxtion of existing hours requirements in the United States will be necessary.

\section{5 .}

Since the success of a democracy in war depends upon the willing and voluntary cooperation of all elements of the population, repressive and coercive measures must be avoided wherever possible. As respects labor, it is necessary that it should not be embittered by the knowledge that other groups in the community are improving their economic position at the workers' expense. Social gains must be preserved-which is to say that the emergency must not be allowed to become an excuse for upsetting the balance of power between workers and employers previously sanctioned by law or worked out by mutual consent.

Embittered and resentful labor will not make a contribution to the war effort on the level of maximum effectiveness. The worker must have cause to feel that the declared objectives of democracy are real and that he himself has a large stake in the outcome. This means that he and his wife and children must be assured of the reasonable, basic satisfactions of life. It means that they must be housed in decency, even though Government must step in to supplement the housing efforts of private builders. It means that adequate provision must be made for the health of the worker and his family and that schooling must be supplied for his children. These are minimum essentials.

In time of wars and jangled nerves it is natural to seek out and stigmatize scapegoats for manifest national shortcomings. We must be on guard against the attempts of those whose eyes are much more on the perennial struggle for power and privilege than upon the trial at arms to nominate our scapegoats for us.

We cannot win without miracles of production, and we cannot achieve such miracles without the wholehearted cooperation of ownership, management, and labor. Whoever foments division among them now is rendering aid and comfort to the enemy. 